П. Б. Ткач

\title{
КОМПОНЕНТИ СЕМАНТИКИ ВІДДАННЯ ПЕРЕВАГИ У СТРУКТУРІ ВИСЛОВЛЕННЯ
}

Ткач П. Б. Компоненти семантики віддання переваги у структурі висловлення.

Стаття присвячена виявленню семантичних особливостей висловлень зі значенням віддання переваги. 3'ясовано, що віддання переваги є специфічним змістовим відношенням, яке формується на основі значення порівняльної оцінки й надає висловленню іллокутивної сили.

Ключові слова: віддання переваги, альтернатива, порівняльна оцінка, мотивація, вибір.

Ткач П. Б. Компоненты семантики предпочтения в структуре высказывания.

Статья посвящена анализу высказываний со значением предпочтения с учётом их семантических. Выяснено, что предпочтение является специфическим смысловым отношением, которое формируется на основе значения операциональной сравнительной оценки и придаёт высказыванию иллокутивную силу.

Ключевые слова: предпочтение, альтернатива, сравнительная оценка, мотивация, выбор. 
Tkach P. B. Semantic components of the Preference in the Structure of the Utterance.

The article represents an analysis of the utterance with the meaning of preference in light of their semantic peculiarities. The preference attributing illocutionary force to an utterance has specific semantic characteristics formed on the base of the meaning of operational comparative valuation.

Key words: preference, alternative, comparative valuation, motivation, choise.

Здавна філософи зверталися до поняття цінностей як основи розуміння людської особистості й людських стосунків, водночас оцінні висловлення привертають активну увагу також і мовознавців (Ю. Д. Апресян, Н. Д. Арутюнова, О. М. Вольф, А. Вежбицька, Т. А. Космеда, О. Д. Шмельов). Сучасні семантичні дослідження звертаються до проблеми віддання переваги, яка використовується як відправний пункт в обговоренні таких понять, як мотивація, вибір, користь. Однак на сьогодні немає грунтовної праці, присвяченої дослідженню семантики віддання переваги, розв'язання ж окремих питань із цієї теми слугує для аналізу інших, опосередковано пов'язаних 3 нею проблем, таких, як оцінка, порівняння тощо, що й визначає актуальність розвідки.

Більшість дослідників погоджується $з$ тим, що оцінку не можна відділити від порівняння через те, що об'єкт можна оцінити, тільки порівнюючи його 3 іншими об'єктами. Відповідно, порівняння визначається як первинний компонент оцінки, представлений як засіб пізнання, що виявляє себе у всіх сферах людської діяльності, як один iз чинників процесу відображення дійсності у свідомості людини і відтворюваній нею мовній діяльності [3, с. 5].

На семантичному рівні для з'ясування сутності й аналізу значення віддання переваги, які виражають ціннісне порівняння, необхідно дати визначення таких понять, як оцінка, зокрема альтернатива, порівняльна оцінка, зіставлення, вибір.

Альтернатива (франц. alternative, от лат. alter - один 3 двох) - це необхідність вибору однієї 3 двох або кількох взаємовиключних можливостей, а також кожна з цих можливостей, наприклад:

[Гапка. В достатках і щзастя, і талан!..

Захарко. А чи так ти міркувала, як була молодою?

Гапка. Дурна була, через те чорт зна як $і$ міркувала.] Краще зазнати на своїм віку достатків, ніж кохання. [3 кохання кожуха не зшиєш!..] (М. Кропивницький).

Мінімумом альтернативи вважають протиставлення реалізації дії не 
реалізації (здійснення-нездійснення, наявність-відсутність, можливістьнеможливість та ін.), вираженню якого служать ствердження i заперечення: [... На Хацุапетівці нічого не робиться так, щุоб інші про иче не знали... А спробуйте непомітно гіллячку додому принести $і$ сховати. Вже коли принесли, то] ліпше не ховайте: [балачок і так не обминути] (Є. Гуцало); Іноді людині ліпше не бачити, не чути, не знати. [Тоді можеш зосередитися на собі самій, спитати себе: щуо я можу знати? Що повинна робити? На щз сподіватися?] (П. Загребельний). Заперечення певного стану речей у головній частині висловлення зі значенням віддання переваги передбачає ствердження цього стану речей у попередньому або наступному контексті, пор.: [Вже коли принесли, то] ліпше не ховайте, ніж пробуйте сховати. Або ствердження міститься вже в самому запереченні, тобто імпліцитно, пор.: Іноді людині ліпше не бачити, не чути, не знати, ніж бачити, чути, знати.

Альтернативність зумовлює зіставлення пропозицій у семантичній структурі висловлення зі значенням віддання переваги. Формування зіставного значення - це вираження відношення між двома подібними чи різними ситуаціями за наявності спільного для них елемента.

Зіставлення, яке міститься в семантиці віддання переваги, відображає невідповідність, розрізнення представлених альтернатив й іноді виходить назовні, будучи вираженим за допомогою сполучника a: [А щуоб вона (удова - П. Т.) не діждала!] Я вже лучче озьму Хвенну, ось щзо за Терешком Бульбахом, коли овдовіє, а ї̈ не хочу (Г. КвіткаОснов'яненко).

Зіставлення може виражатися в конструкціях віддання переваги і без залучення сполучних засобів: [...nочт імператрищин збуджено замепотів, вважаючи, щуо охорониі віддають шану сановності їхньої господині,] сама ж Свпраксія незвичайну поведінку норманів воліла б сприйняти як вияв уважливості до неї особисто, не до імператриці-до ж⿻іки, зовсім молодої, неймовірно вродливої жінки! (П. Загребельний). У художній літературі поєднання такого типу виконують експресивну функцію, пор.: Сама ж Свпраксія незвичайну поведінку норманів воліла б сприйняти як вияв уважливості до неї особисто як до жінки, зовсім молодої, неймовірно вродливої жінки, ніж як до імператриці!

Необхідною умовою формування значення віддання переваги $\epsilon$ контекстуальна інформація, яка підтверджує зіставлюваність двох пропозицій. Відношення невідповідності, що виникає між пропозиціями у висловленнях із таким значенням, вимагає пошуків підстав для 
визначення переважності, бажаності однієї з них, їх мотивації.

Суб'єкт віддання переваги моделює уявну ситуацію, яка випливає 3 його потреб і яка є альтернативною до іншої, уявної або реальної. Саме $з$ цих двох ситуацій йому належить здійснити вибір. Яким буде цей вибір, залежить від уявлення про його наслідки. Наслідки вибору можуть бути не тільки позитивні, але й негативні, але обов'язково кращі порівняно з іншими, ще гіршими. Ці наслідки і мотивують вибір на користь певної ситуації.

Оцінювання мовцем стану речей або поведінки співрозмовника за параметрами добре - погано, доцільно - недоцільно, корисно шкідливо тощо надає мотивації більшої виразності й переконливості, що й стає підставою для віддання переваги. Підстави для віддання переваги становлять докази, за якими суб'єкт (мовець або діяч) здійснює порівняльну оцінку.

Коли мовець обирає підстави, за якими оцінює й обирає одну 3 альтернатив, він виходить із власного досвіду, а також ураховує наслідки й перспективи вибору для учасників ситуації. Такими підставами можуть бути: досвід, фонові знання, етичні оцінки, передбачення наслідків, реалістичність (можливість) здійснення, життєва позиція, світогляд та ін. Усі ці підстави пов'язані з мовцем як із суб'єктом дії. Ті самі підстави можуть ураховуватися мовцем як основа для вибору, здійснюваного слухачем (адресатом) або третьою особою. Таким чином, підставами для віддання переваги є уявлення мовця (фонові знання, світогляд тощо) або знання мовця стосовно уявлень або інтересів особи, яка здійснює вибір.

Підстави формують мотив для мовця (слухача або іншої особи) віддати перевагу певній ситуації. Мотиваційний компонент обов'язковий елемент у структурі висловлення віддання переваги, але його експлікація не завжди потрібна. Саме тому він може по-різному виражатися в конструкції зі значенням віддання переваги.

Так, є висловлення, які потребують експлікації мотиваційного компонента, наприклад: Лучче б ти, сякий-такий сину, дурнем ріс би дома, [ніхто б і не знав, щчо ти єси дурень; а тепер усяк бачить, щцо ти вернувся більшим дурнем, чим був...] (Г. Квітка-Основ'яненко). Друга пропозиція цього висловлення не експлікована у структурі висловлення через те, що вона відрізняється від першої заперечним характером того ж самого змісту. Заперечення виводиться з наступного контексту: вернувся - отже, раніше пішов із дому, тобто краще б був дома, ніж пішов з дому. Підставами для віддання мовцем переваги $€$ () П. Б. Ткач, 2014. 
знання про негативний (із погляду самого мовця) наслідок реалізованої ситуації (усяк бачить, щзо ти вернувся більшим дурнем, чим був).

Необхідність експлікації мотиваційного компонента випливає із суб'єктивності значення віддання переваги: бажання мовця не завжди збігаються із загальноприйнятими нормами, і це зумовлене тим, що мовець має власні, суб'єктивні, мотиви, а саме власні уявлення про негативні наслідки (наприклад, те, що люди побачать, яким дурнем повернувся син мовця, не було б для іншої людини достатньою підставою для вибору). Експлікація мотиваційного компонента дає змогу мовцеві обгрунтувати свої бажання в ситуації, коли його вибір має суто суб' єктивний характер.

Є висловлення віддання переваги, де мотиваційний компонент міститься імпліцитно, наприклад: [Навчає баєчка великого й малого, Бо заповідано давно, Що] краще зернятко своє одно, Ніж иілі ворохи чужсого (Л. Глібов). Експлікація мотиваційного компонента не $\epsilon$ необхідною для розуміння вибору мовця через те, що мотивацією тут $\epsilon$ загальновизнане правило, що своє - це добре, а чуже - погано.

Висловлення зі значенням віддання переваги самі можуть виступати мотивацією вчинків мовця, слухача або іншої особи, наприклад: Султани, надаючи перевагу величі, сказати б, таємничій, не стали користуватися великими дверима, [якими входили до Софії всі візантійські імператори... У східній стіні Софї навпроти брами Великого палаиу Фатіх звелів пробити вхід для султанів...] (П. Загребельний). У цьому разі пропозиція, що позначає ситуацію, якій мовець віддає перевагу, є мотивацією втілення вибору семантичного суб'єкта в дійсність, пор.: Султани не стали користуватися великими дверима, бо надавали перевагу величі, сказати б, таємничій.

Специфіка висловлень віддання переваги з компаративами краще (ліпше) в тому, що вони встановлюють не кількісне співвідношення наявної в порівнюваних об'єктах ознаки, як за звичайного порівняльного оцінювання, а співвідношення плюсів і мінусів, які характеризують різні події [1, с. 332]. Ці плюси та мінуси і є підставами, 3 огляду на які віддається перевага. Саме наявність цих підстав i визначає специфічність порівняльної оцінки, яка формує значення віддання переваги, і відрізняє іiі від інших типів порівняльної оцінки.

Компаратив краще (ліпше) вводить пропозицію, на користь якої треба здійснити вибір, а не пропозицію, якої слід уникнути [2, с. 231], наприклад: Лучче з доброго коня впасти, ніж на поганому їхати 
(Номис). Саме тому компаратив гірше є неможливим для конструкцій віддання переваги, адже вони програмують дії, метою суб'єкта-мовця є встановити, як краще вчинити, а не як вчинити гірше.

Альтернативні ситуації можуть порівнюватися й оцінюватися не тільки $з$ точки зору того, що краще, але й з інших позицій. Так, ситуації можуть оцінюватися з позиції більшої ймовірності однієї альтернативи порівняно з іншою. Це висловлення з компаративом скоріше (швидше): [Ступай. Принаймні по-українському звернувся: «Збирайся на смерть», а не «Готовся к смерти». Матрос!] А генерал Перочький скоріш сам собі смерть заподіє, ніж промовить слово украӥнське (М. Куліш). Друга ситуація здається мовцеві настільки неможливою, що порівняно 3 нею ймовірним стає навіть самогубство або бажання дівчини піти у монастир. У таких конструкціях підкреслюється неможливість однієї ситуації, на фоні якої інша сприймається як імовірна незалежно від того, наскільки вона ймовірна насправді, наприклад: [Микита.] Забути? Hi, скоріш перестане серие битись у грудях, очі мої не зглянуть на світ сония, ніж я забуду, щзо я був і щзо я тепер! (М. Кропивницький).

Друга альтернатива завжди набуває статусу неприйнятної, неймовірної, навіть попри те, що вона може бути адекватною сутності описуваного, наприклад: ...mільки почув Саїд з уст свого нового знайомого щуось подібне скоріше на лайку, аніж на прізвище (I. Ле). Кваліфікація почутого, представлена другою альтернативою, є цілком справедливою, але мовець віддає перевагу зовсім іншій версії, позначаючи іï як більш імовірну: так він прагне підкреслити більш суттєве в тому, про що йдеться, його характерну рису або ознаку.

За відсутності компаративів краще, скоріше, швидше конструкції зі значенням віддання переваги не містять вказівки на те, що обрана альтернатива $\epsilon$ кращою або більш імовірною, отже, порівняльна оцінка міститься в їх семантиці імпліцитно, зумовлюючи певний вибір, наприклад: [Найкоротша дорога за місто веде попри кладовище.] Ольга воліла обминути ц̧е місие... (І. Вільде).

Етап вибору $є$ обов'язковим у формуванні значення віддання переваги. Зважуючи існуючі альтернативи, мовець робить висновок про переваги того чи іншого вибору для реалізації його мети, і одна 3 пропозицій позначається як така, якій віддається перевага, наприклад:

[Павло. Шкода ж, сину, потеря: землі купили задешево, завдаток дали, весною банк гроші дасть - $і$ земля наша на вічність...

Михайло. Не хочу я, тату!] Легше мені і краще мені наймитом (C) П. Б. Ткач, 2014. 
жить у своїи стороні, аніж тут, у цій пустині, мать землю на вічність (І. Карпенко-Карий).

Зв'язок з вибором надає висловленню операційності (дієвості), що становить найважливішу ознаку віддання переваги. Оскільки вибір передує вчинку, висловлення віддання переваги співвідносяться 3 тим життєвим контекстом, який визначається тріадою віддання переваги (вибір) - рішення - дія [2, с. 171]. Операційність програмує дію, тому висловлення віддання переваги - це не просто вибір 3 можливих альтернатив, але й прийняття рішення з метою втілити його в життя: Лучче мені руку утять, лучче мені очей рішитися, чим віддати славу моєї дочечки на поругательство! (Г. Квітка-Основ'яненко), пор.: Я не віддам славу дочки на поругательство. Людина приймає рішення, враховуючи певні підстави, і може перейти до здійснення свого наміру.

Вибір може здійснюватися суб'єктом віддання переваги як у власних інтересах, так і в інтересах іншої особи. Здійснення вибору, як згадувалося, передбачає його мотивацію.

Місце вибору в семантичній структурі висловлення віддання переваги визначається відповідно до інтерпретації наміру мовця: чи є для нього головною оцінка, а вибір виникає як ії органічний наслідок, чи він моделює саме дію вибору, якій підпорядковується оцінка. У структурі висловлень другого типу експлікується вибір (лексеми віддавати перевагу, воліти). Висловлення такого зразка можуть позначати вибір мовця безвідносно до експлікації позитивної чи негативної оцінки мовцем певної ситуації, наприклад: [...султан, коли його мати якось натякала, щчо могла б розкрити йому очі на походження одної занадто дорогої для нього людини, недбало відмахнувся $і$ не захотів слухати.] Волів жити із заплющенили очима, сліпим, незрячим! (П. Загребельний).

Вибір також може експлікуватися самостійно: як компонент значення віддання переваги він експлікується у висловленні за умови вживання в них специфічних для цього значення лексем, а саме вживання предикатних лексем вибирати, обирати, у лексичному значенні яких присутній компонент вибору й відповідно семантика віддання переваги, наприклад: [Поліксена. Негарно заздрити сестрі, Кассандро, Не винна я, щзо Ахіллес мене, А не тебе з усіх циарівен вибрав... (Леся Українка). Тут значення віддання переваги виражається за допомогою лексеми вибирати, альтернатива ж, яка відкидається, уводиться сполучником а не, пор.: Ахіллес віддав перевагу мені перед тобою, тобто вибрав мене. [Якщо вибирати між красою і правдою,] я 
вибираю красу. [У ній більш глибокої істини, ніж у одній лише голій правдi. Істинне тільки те, щзо прекрасне] (із «Щоденника» О.П. Довженка), пор.: Я віддаю перевагу красі, а не правді.

У висловленнях зі значенням віддання перевагиможе експлікуватися наступний етап - утілення здійсненого вибору в життя. На цьому етапі репрезентуються наслідки вибору мовця (або іншої особи). Цей етап належить позамовній дійсності, але може бути представленим у контексті віддання переваги, наприклад: Султани, надаючи перевагу величі, сказати б, таємничій, не стали користуватися великими дверима, [якими входили до Софії всі візантійські імператори... У східній стіні Софії навпроти брами Великого палащу Фатіх звелів пробити вхід для султанів...] (П. Загребельний). У висловленнях такого типу етап вибору, як уже зазначалося, слугує для мотивації дій мовця або іншої особи у випадках, коли виникає потреба в їх поясненні: [Степан. Не задля соболів, не для казни Подався на Москву небіжчик батько! Чужсим панам служити в ріднім краю Він не хотів,] волів вже на чужині Служити рідній вірі, помагати Хоч здалека пригнобленим братам, [Сднаючи для них цุареву ласку] (Леся Українка).

Підсумовуючи викладений аналіз щодо умов формування у висловленні значення віддання переваги, можна зробити такі висновки: наявність двох альтернатив, репрезентованих двома пропозиціями, i визначення їх невідповідності (зіставлення) передбачає оцінку однієї альтернативи (пропозиції) порівняно 3 іншою, тобто визнання однієї ситуації кращою-гіршою або більш-менш імовірною за іншу. Порівняльна оцінка є мотивом для здійснення вибору. Відповідно значенню віддання переваги властиві такі диференційні ознаки, як альтернативність змісту; зіставлення альтернатив; наявність мотиваційного компонента, який відбиває пошук підстав для порівняльної оцінки; порівняльна оцінка, яка зумовлює вибір; відображення ситуації вибору; можливість повідомлення про втілення здійсненого вибору в життя.

\section{Література}

1. Арутюнова Н. Д. Сравнительная оценка ситуации / Н. Д. Арутюнова // Известия АН СССР. Серия лит. и яз. - 1983. - Т. 42. - № 4. - С. 330-341.

2. Арутюнова Н. Д. Язык и мир человека / Н. Д. Арутюнова. - М. : Языки русской культуры, 1999. - 896 с.

3. Прокопчук Л. В. Категорія порівняння та іï вираження в структурі простого речення : автореф. дис. ... канд. філол. наук / Л. В. Прокопчук. - К., 2000. - 18 с.

Стаття надійшла до редакиї 21.10.2014 p. 